\title{
Prioritising the respiratory research needs of primary care: the International Primary Care Respiratory Group (IPCRG) e-Delphi exercise
}

\author{
*Hilary Pinnocka, Anders Østrem ${ }^{b}$, Miguel Román Rodríguezc, Dermot Ryan ${ }^{\mathrm{d}}$, \\ Björn Ställberge, Mike Thomas ${ }^{f}$, loanna Tsiligianni ${ }^{9}$, Sian Williams ${ }^{h}$, Osman Yusufi
}

\author{
a Senior Clinical Research Fellow, Allergy and Respiratory Research Group, Centre for Population Health Sciences, University of Edinburgh, \\ Edinburgh, UK \\ b General Practitioner, Gransdalen Legesenter, Oslo, Norway \\ Son Pisa Primary Health Care Centre, Palma de Mallorca, Spain \\ d Honorary Clinical Research Fellow, Allergy and Respiratory Research Group, Centre for Population Health Sciences, University of Edinburgh, \\ Edinburgh, UK \\ e Department of Public Health and Caring Sciences, Family Medicine and Clinical Epidemiology, Uppsala University, Uppsala, Sweden \\ Asthma UK Senior Research Fellow, Centre for Academic Primary Care, University of Aberdeen, UK \\ ${ }^{9}$ University Medical Center of Groningen, Groningen, The Netherlands

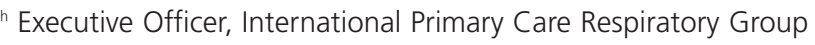 \\ Chief Primary Care/GP Trainer, and Consultant Allergy and Asthma Specialist, The Allergy and Asthma Institute, Islamabad, Pakistan
}

Received 2nd December 2011; revised 5th January 2012; accepted 7th January 2012; online 24th January 2012

\begin{abstract}
Background: Community-based care, underpinned by relevant primary care research, is an important component of the global fight against non-communicable diseases. The International Primary Care Research Group's (IPCRG's) Research Needs Statement identified 145 research questions within five domains (asthma, rhinitis, chronic obstructive pulmonary disease (COPD), smoking, respiratory infections). Aims: To use an e-mail Delphi process to prioritise the research questions.

Methods: An international panel of primary care clinicians scored the clinical importance, feasibility, and international relevance of each question on a scale of 1-5 ( $5=$ most important). In subsequent rounds, informed by the Group's median scores, participants scored overall priority. Consensus was defined as $80 \%$ agreement for priority scores 4 or 5 .

Results: Twenty-three experts from 21 countries completed all three rounds. Sixty-two questions were prioritised across the five domains. A recurring theme was for 'simple tools' (e.g. questionnaires) enabling diagnosis and assessment in community settings, often with limited access to investigations. Seven questions recorded $100 \%$ agreement: these involved pragmatic approaches to the diagnosis of COPD and rhinitis, assessment of asthma and respiratory infections, management of rhinitis, and implementing asthma self-management.

Conclusions: Evidence to underpin the primary care approach to diagnosis and assessment and broad management strategies were overarching priorities. If primary care is to contribute to the global challenge of managing respiratory non-communicable diseases, policymakers, funders, and researchers need to prioritise these questions.

(C) 2012 Primary Care Respiratory Society UK. All rights reserved.

H Pinnock et al. Prim Care Respir J 2012; 21(1): 19-27

http://dx.doi.org/10.4104/pcrj.2012.00006
\end{abstract}

Keyw ords non-communicable diseases, primary care, research priorities, respiratory medicine, IPCRG

The full version of this paper, with online Appendices, is available at www.thepcrj.org

\footnotetext{
* Corresponding author: Dr Hilary Pinnock, Allergy and Respiratory Research Group, Centre for Population Health Sciences, The University of Edinburgh, Doorway 3, Medical School, Teviot Place, Edinburgh EH8 9AG, UK.

Tel: +44(0)1316508102 Fax: +44(0)1316509119 E-mail: hilary.pinnock@ed.ac.uk
} 
See linked editorial by Holgate on pg 1

\section{Introduction}

In September 2011 the General Assembly of the United Nations (UN) adopted a declaration on the Prevention and Control of Non-communicable Diseases (NCDs) which highlighted the 'rapidly growing magnitude of NCDs affecting people of all ages, gender, race and income levels'. ${ }^{1}$ Acknowledging that the impact of NCDs (specifically including chronic respiratory disease) could be 'significantly reduced', the UN declaration encouraged a range of political, societal, and healthcare initiatives 'especially at the primary healthcare level'. Professional organisations actively supported the campaigning that led to this initiative..$^{2-4}$

Pre-empting the UN call for facilitation of translational research to inform national and global action, ${ }^{1}$ research agendas have been published from different professional and geographical perspectives. ${ }^{4-6}$ In line with the Action Plans of the World Health Organization, these emphasise the pivotal importance of evidence-based primary healthcare, ${ }^{7,8}$ although none explores the challenge specifically from the primary care perspective.

In June 2010 the International Primary Care Respiratory Group (IPCRG) began the process of addressing this gap by publishing a Research Needs Statement (RNS). ${ }^{9}$ It was hoped that the statement would be used by clinicians and patients campaigning for answers to questions relevant to the delivery of respiratory care in the community, to support researchers seeking funding to provide answers to these questions, and to inform funding bodies prioritising research agendas. An overarching theme was the need for research undertaken within primary care, recruiting participants representative of primary care populations, evaluating interventions realistically delivered over appropriate timescales within primary care, and drawing conclusions that will be meaningful to professionals working within primary care. The recent surge of interest in 'real-life' research reflects the importance of this agenda. ${ }^{10-12}$

\section{Development of the IPCRG Research Needs Statement}

The list of research questions in the RNS was compiled using an informal but inclusive consultation process. ${ }^{9}$ Draft statements in asthma, rhinitis, chronic obstructive pulmonary disease (COPD), tobacco dependence, and respiratory infections were circulated widely to a total of 42 participants from 22 countries including IPCRG members, other recognised experts, and representatives from a range of economic and healthcare backgrounds. Following an iterative process, a total of 145 questions was generated across five disease areas (asthma, $n=47$; allergic rhinitis, $n=26$; COPD, $n=35$; tobacco dependence, $n=16$; respiratory infections, $n=21$ ). Disease-specific questions focused on effective and cost-effective ways to prevent disease, confirm a diagnosis, assess control, manage treatment, and empower self-management. Practical questions were highlighted about how to deliver this comprehensive agenda in the diverse primary care settings of low and middle income countries as well as relatively well-resourced healthcare systems.

Within this broad agenda, however, there was a need to prioritise and, in 2011, the IPCRG commissioned an e-Delphi consensus process to identify the priority research questions in each disease domain of the RNS.

\section{Methods \\ Ethics}

We were advised by the South East Scotland research ethics service that we did not require ethical approval for this study (personal communication, 17 December 2010).

\section{e-Delphi methodology}

Originating from the RAND Corporation in the $1950 \mathrm{~s}^{13}$ the Delphi method is a technique for reaching consensus among experts about topics for which there is limited evidence. ${ }^{14-17}$ The underlying concept is that an expert panel is recruited, the members of which contribute ideas and then rank suggestions in successive rounds until predefined consensus is reached. In each round, responses are influenced by summary feedback from previous rounds; however, the panellists work independently and their contributions are anonymous, thus giving equal weight to all perspectives and overcoming the potential bias introduced by powerful opinionated minorities in consensus meetings. ${ }^{17}$ As face-to-face discussion is not required, the exercise can be administered by e-mail. The technique has been widely used in a range of healthcare contexts including defining the components of an anaphylaxis plan, ${ }^{18}$ identifying safety standards of GP computer systems, ${ }^{19}$ and prioritising research needs within the UK. ${ }^{20}$

\section{The IPCRG e-Delphi}

We undertook an international e-Delphi exercise which differed from the classic description in two important ways:

- We omitted the first step in which the expert panel is asked open questions and invited to contribute ideas for subsequent ranking. ${ }^{14,16}$ Instead, we started with the 145 research questions of the RNS which had already been generated by wide discussion among international experts in the field.

- A number of constructs (clinical importance, feasibility, and international relevance) were identified by the international research team as contributing to the final ranking of the priority of the research questions. To ensure that participants considered all three aspects, in the first round we asked the panel to score each question against each of the three constructs and then in the second and subsequent rounds to take an overview of the rankings as a priority for the IPCRG.

\section{Recruitment of an expert panel}

The IPCRG is an umbrella organisation for 18 national primary care respiratory organisations and 28 individual associate members from countries with no national organisation. To achieve a broad geographical spread, we aimed to recruit an expert panel with representatives of primary care-based clinicians 
from our member countries and as many as possible of the associated countries, ensuring that we also encompassed relevant clinical, research, and educational expertise. ${ }^{15,17}$ We compiled a list of:

- Authors and contributors of the RNS (excluding the team conducting the Delphi exercise).

- Members of the IPCRG research sub-committee and research network.

- Representatives of the member and associate member countries.

- Members of the IPCRG education sub-committee and panel. After removing duplication, the potential pool was 63 people from 34 countries. An e-mailed invitation was sent to all potential members which included a description of the process, the anticipated timescale, and the estimated commitment. We made it clear that we expected participants to contribute to all three rounds.

\section{Piloting}

We piloted the process to ensure that the instructions were clear, data collection was feasible, and the process of data entry, analysis and feedback of results at each round was streamlined. Minor adjustments were made to the instructions to improve clarity.

\section{The e-Delphi consensus process}

Figure 1 illustrates the flow of the e-Delphi consensus process which took place over 5 months in Spring 2011. In each of the three rounds, panel members were asked to return their completed spreadsheets within 2 weeks, with a reminder being sent a few days before the deadline. A second reminder was sent to non-responders the day after the due date with a 3-day deadline.

\section{Round 1}

The research questions were reproduced verbatim from the RNS on an Excel spreadsheet (Microsoft Corporation, Washington, USA). Panel members were asked to score each research question on a scale of 1-5 against three constructs (where 1 is the least and 5 is the most important/feasible/international ly relevant).

- Importance for primary care practice: Participants were asked to answer the following question from their perspective as a primary care clinician and/or researcher. "How important is it for improving the care of people with respiratory conditions in your healthcare system to have the answer to this question?"

- Feasibility to be conducted in primary care: Participants were asked to consider the following question from their perspective as a primary care clinician and/or researcher. "How feasible do you think a research project in this area would be in your healthcare setting?"

- Potential for international collaboration: "What is the potential for collaborative research to answer this question involving a number of countries, either working together or comparing between healthcare systems?"
Figure 1. Flow diagram of the e-Delphi process

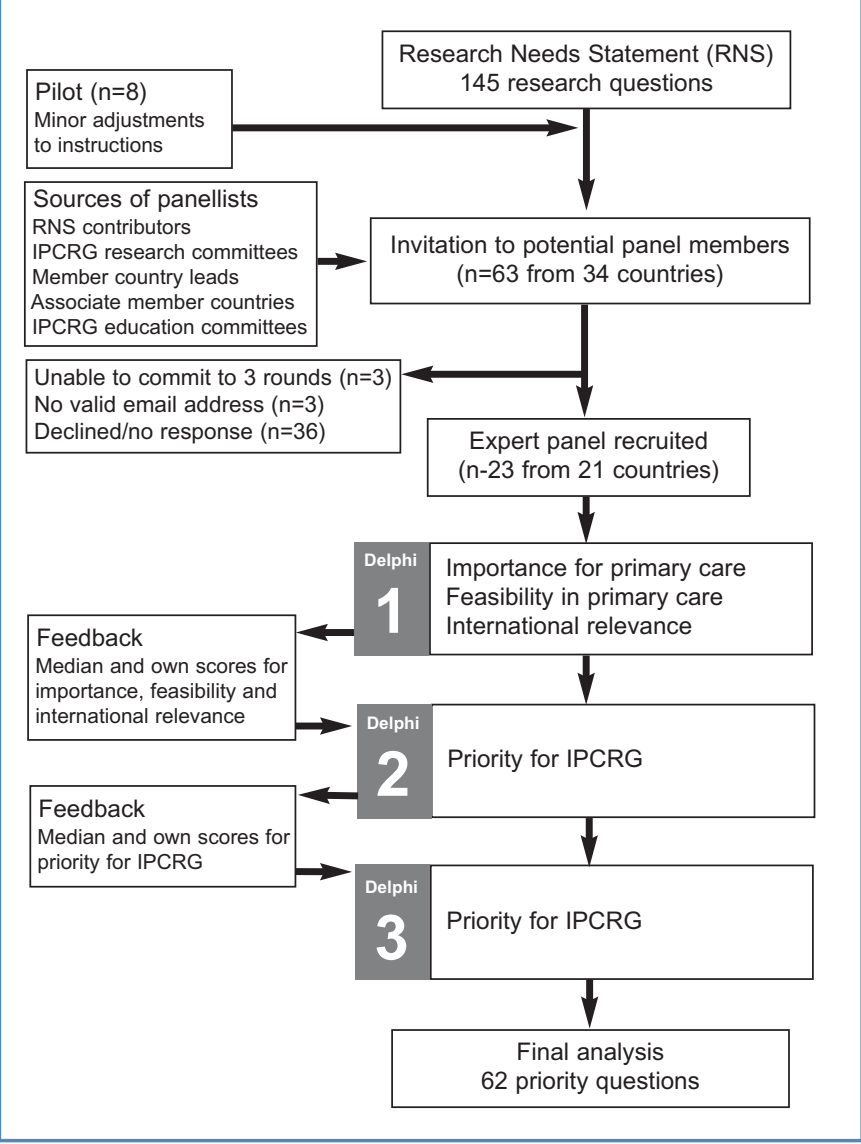

The results were collated onto an Excel spreadsheet and a median score was calculated for each of the three constructs.

\section{Round 2}

The second round spreadsheet included the median scores from round 1 for each of the three constructs as well as the participant's own score. Respondents were asked to trade off or balance the importance, feasibility, and international relevance of each question and to decide on the priority of each question for the IPCRG.

- Overall priority: Participants were asked to score the overall priority for the IPCRG ("Which of these research questions should the IPCRG invest time, money and effort in trying to answer?"), allocating a score of 1-5 (where 1 is the lowest and 5 is the highest priority).

The results were collated onto an Excel spreadsheet and an overall median score was calculated for each research question.

Round 3

The median scores for each question were entered onto the round 3 spreadsheet and fed back to individual panel members along with their own score. ${ }^{14}$ Panel members were then given the opportunity to revise their opinions on the overall priority of each question for the IPCRG in the light of the findings of the previous round by again ranking each research question on a score of $1-5$. 
Table 1. Countries of origin and professional background of the expert group

\begin{tabular}{lll} 
Region & Countries & Professional role \\
\hline Northern Europe & $\begin{array}{l}\text { Sweden, Netherlands, } \\
\text { Norway, UK, Denmark, } \\
\text { Germany }\end{array}$ & $\begin{array}{l}5 \text { Academic GPs } \\
1 \text { Clinical GP }\end{array}$ \\
\hline Southern Europe & $\begin{array}{l}\text { Greece, Portugal, Turkey, } \\
\text { Spain, Italy }\end{array}$ & $\begin{array}{l}4 \text { Academic GPs } \\
1 \text { Clinical GP }\end{array}$ \\
\hline $\begin{array}{lll}\text { Russia and Eastern } \\
\text { Europe }\end{array}$ & Russia, Romania, Poland & $\begin{array}{l}\text { 1 Allergy specialist } \\
\text { 2 Clinical GPs }\end{array}$ \\
\hline $\begin{array}{l}\text { Indian and the Far } \\
\text { East subcontinent }\end{array}$ & India, Singapore, & 2 Academic GPs \\
\hline South and North & Chile, Argentina, Canada & 3 Clinical GPs \\
America & & \\
\hline Australasia & Australia, New Zealand & 1 Academic GP \\
& & 2 Educationalist GPs \\
\hline
\end{tabular}

\section{Analysis of data}

We calculated median scores for each of the questions and the proportion of respondents agreeing that the question was a priority. ${ }^{17}$ Consensus was defined a priori as $80 \%$ agreement for the priority score of 4 or 5 . We anticipated that three rounds would allow an acceptable degree of agreement on research priorities but, if not, a final fourth round using the format of round 3 would be undertaken.

In order to enable overarching themes to be identified, four members of the research team (HP, BS, IT, AO) coded the questions into categories (e.g. diagnosis, management, organisation of care). Disagreements were resolved by negotiation.

\section{Results}

We recruited 23 participants from 21 countries to the expert panel. Table 1 lists the countries of origin and professional background of the participants. Participants included 11 (61\%) of the IPCRG member countries and 10 (36\%) of the associate member countries. All the participants completed all three rounds.

\section{Proportion reaching consensus thresholds}

Of the 145 research questions, 62 achieved the a priori consensus level of $80 \%$ agreement with priority scores of 4 or 5 . Seven questions achieved $100 \%$ agreement and 24 reached a consensus threshold of $90 \%$. The prioritised questions were evenly distributed across all five disease domains (Table 2).

\section{Prioritised questions in each disease domain}

The 62 questions in the five disease domains prioritised at the $80 \%$ threshold are listed in Tables 3-7. All the seven questions achieving 100\% consensus emphasised the need for a practical 'primary care approach'. Two questions were in the asthma domain ('simple' tools for assessing control and implementing selfmanagement), two in the allergic rhinitis domain (diagnosing the
Table 2. Number of questions prioritised in each domain and category

Number of questions at each threshold

$\begin{array}{llll}\text { RNS } & 80 \% & 90 \% & 100 \%\end{array}$

Disease domain, $\mathrm{n}$ (\% of RNS questions)

\begin{tabular}{lllll} 
All & 145 & $62(43 \%)$ & $24(17 \%)$ & $7(5 \%)$ \\
\hline Asthma & 47 & $20(43 \%)$ & $9(19 \%)$ & $2(4 \%)$ \\
Allergic rhinitis & 26 & $9(35 \%)$ & $3(11 \%)$ & $2(8 \%)$ \\
COPD & 35 & $19(54 \%)$ & $6(17 \%)$ & $2(6 \%)$ \\
Tobacco dependence & 16 & $9(56 \%)$ & $2(13 \%)$ & 0 \\
Respiratory infections & 24 & $5(21 \%)$ & $5(21 \%)$ & $1(4 \%)$ \\
\hline
\end{tabular}

Category, $\mathrm{n}$ (\% of questions at that threshold)

Management $\quad 23(16 \%) \quad 12(19 \%) \quad 6(25 \%) \quad 1(14 \%)$

Organisation $\quad 21(14 \%) \quad 5(8 \%) \quad 0 \quad 0$

Diagnosis $\quad 20(14 \%) \quad 12(19 \%) \quad 9(38 \%) \quad 4(57 \%)$

Assessment $\quad 20(14 \%) \quad 17(27 \%) \quad 7(29 \%) \quad 1(14 \%)$

Self-management $12(8 \%) \quad 3(5 \%) \quad 1(4 \%) \quad 1(14 \%)$

$\begin{array}{lllll}\text { Prevention } & 9(6 \%) & 2(3 \%) & 0 & 0\end{array}$

Pharmacological $\quad 8(6 \%) \quad 2(3 \%) \quad 0 \quad 0$

CPD $\quad 8(6 \%) \quad 3(5 \%) \quad 0 \quad 0$

Further tests $\quad 6(4 \%) \quad 1(2 \%) \quad 1(4 \%) \quad 0$

Co-morbidity $\quad 6(4 \%) \quad 2(3 \%) \quad 0 \quad 0$

Diversity $\quad 6(4 \%) \quad 0 \quad 00$

Compliance $\quad 5(3 \%) \quad 3(5 \%) \quad 0 \quad 0$

$\begin{array}{lllll}\text { Epidemiology } & 1(1 \%) & 0 & 0 & 0\end{array}$

$\mathrm{CPD}=$ Continuing Professional Development

Figure 2. Prioritisation of the different categories of questions

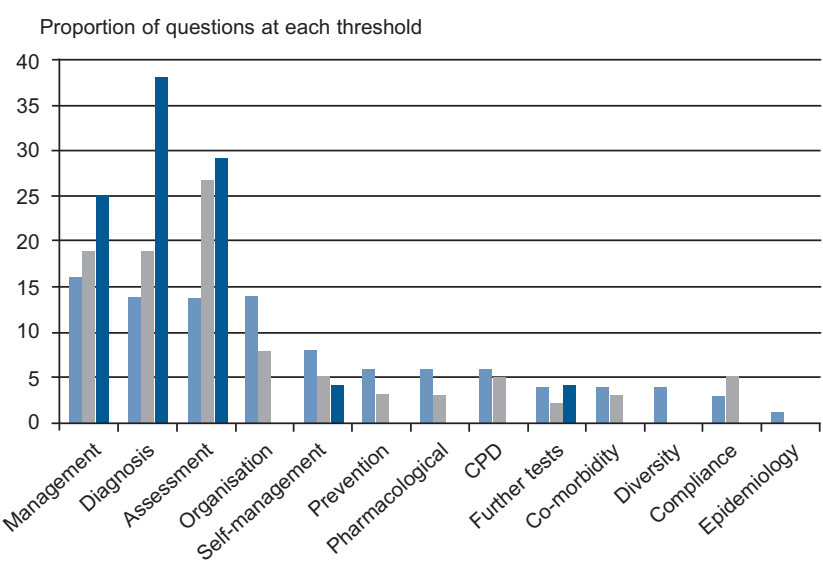

Notes:

RNS The blue bars illustrate the proportion of the 145 questions in the IPCRG Research Needs Statement in the 12 different categories $80 \% \quad$ The dark blue bars illustrate the proportion of the 62 questions prioritised in at the a priori threshold of $80 \%$ agreement with priority scores of 4 or 5 in the 12 different categories

$90 \% \quad$ The grey bars illustrate the proportion of the 24 questions prioritised at the threshold of $90 \%$ agreement with priority scores of 4 or 5 in the 12 different categories.

$\mathrm{CPD}=$ Continuing Professional Development 
Table 3. Consensus on the research priorities in asthma listed in rank order

\begin{tabular}{|c|c|}
\hline Category & Research question \\
\hline Assessment & What simple tools enable assessment of asthma control and is their use acceptable and feasible in primary care? \\
\hline Self-management & How can guided self-management be implemented in real-life primary care practice? \\
\hline Diagnosis & How can asthma be diagnosed earlier in primary care? \\
\hline Management & How and when should regular medication be stepped down or stopped? \\
\hline Diagnosis & $\begin{array}{l}\text { What practical algorithms could distinguish between recurrent wheeze/asthma and other acute respiratory diseases } \\
\text { including pneumonia for young children presenting to primary care? }\end{array}$ \\
\hline Management & How can good and poor inhaler technique be identified and what is the best strategy for ensuring good inhaler technique? \\
\hline Diagnosis & $\begin{array}{l}\text { How can remote areas or developing countries diagnose and manage asthma with limited or no availability of } \\
\text { diagnostic tests? }\end{array}$ \\
\hline Management & How should acute severe asthma be managed in settings where emergency department and hospital are not accessible? \\
\hline Diagnosis & What is the role of symptom-based tools for diagnosing asthma in primary care? \\
\hline Compliance & $\begin{array}{l}\text { What is the impact of patients' comprehension of the disease, use of different treatment strategies, treatment cost } \\
\text { (in high and low income countries and between social groups) and concern about side effects of inhaled steroids } \\
\text { on adherence to prescribed treatment }\end{array}$ \\
\hline Assessment & $\begin{array}{l}\text { What is the importance of co-morbidity (especially psychological morbidity) and socio-economic factors in identifying } \\
\text { those at risk of very severe attacks? }\end{array}$ \\
\hline Compliance & How may these issues of adherence be addressed (especially in sub-groups such as the adolescent patient with asthma)? \\
\hline Management & $\begin{array}{l}\text { What is the preferred management (including appropriate inhalation device) of moderate exacerbations in } \\
\text { primary care, including in clinical situations were treatment options are limited? }\end{array}$ \\
\hline Self-management & Why are professionals reluctant to provide asthma action plans to their patients and how may this be overcome? \\
\hline Assessment & Is an assessment of severity needed in addition to an assessment of asthma control in primary care? \\
\hline Assessment & What is the role of lung function testing, in regular monitoring of asthma patients in primary care? \\
\hline Assessment & $\begin{array}{l}\text { What is the validity and usefulness of questionnaires for assessing quality of life (or other outcomes) when used for } \\
\text { individual patients in routine primary care clinical practice }\end{array}$ \\
\hline Assessment & $\begin{array}{l}\text { What is a practical approach to the assessment of severity of acute asthma in primary care settings with limited } \\
\text { diagnostic resources? }\end{array}$ \\
\hline Organisation & What are effective approaches to developing a partnership with the patient? \\
\hline Management & What is the most effective add-on therapy option to inhaled corticosteroids in different sub-groups of asthma? \\
\hline
\end{tabular}

\section{Table 4. Consensus on the research priorities in allergic rhinitis listed in rank order}

\begin{tabular}{ll} 
Category & Research question \\
\hline Management & What (combinations of) management strategies for treating rhinitis improve asthma control and/or improve quality of life? \\
\hline Diagnosis & $\begin{array}{l}\text { What tools (e.g. validated, symptom-based questionnaires for rhinitis or screening for atopy) could help the primary } \\
\text { care clinician differentiate between allergic and non-allergic rhinitis, rhinosinusitis, common cold and other clinically } \\
\text { similar conditions? }\end{array}$ \\
\hline Assessment & What questions for use in primary care practice will determine rhinitis control and identify those at risk of \\
& worsening symptoms and/or onset of co-morbid asthma? \\
\hline CPD & What are the educational needs of primary care clinicians and how may these be met? Can an educational \\
& intervention improve awareness and clinical skills of GPs and improve clinical outcomes in allergic rhinitis? \\
\hline Compliance & How can compliance with treatments be improved? \\
\hline Management & Is the ARIA classification useful in guiding prescribing in primary care? \\
\hline Prevention & $\begin{array}{l}\text { Does early and aggressive treatment of atopic children with allergic rhinitis (e.g. with topical nasal steroids } \\
\text { and/or immunotherapy) prevent the progression to asthma? }\end{array}$ \\
\hline Assessment & $\begin{array}{l}\text { Are clinicians aware of the asthma-rhinitis link and to what extent do they seek information about allergic rhinitis } \\
\text { when seeing asthmatic patients? }\end{array}$ \\
\hline Management & $\begin{array}{l}\text { What is the best technique for using nasal sprays? What do doctors, pharmacists, and patients know of correct } \\
\text { nasal inhalation technique? }\end{array}$ \\
\hline CPD = Continuing Professional Development.
\end{tabular}


Table 5. Consensus on the research priorities in chronic obstructive pulmonary disease (COPD) listed in rank order

\begin{tabular}{|c|c|}
\hline Category & Research question \\
\hline Diagnosis & $\begin{array}{l}\text { Can the use of a simple validated questionnaire improve the accurate identification of COPD in different countries } \\
\text { (including those without access to spirometry)? }\end{array}$ \\
\hline Diagnosis & $\begin{array}{l}\text { When a primary care approach to the diagnosis of COPD is applied, what is the diagnostic yield compared with } \\
\text { currently accepted diagnostic criteria? }\end{array}$ \\
\hline Diagnosis & $\begin{array}{l}\text { What is the best way to identify and diagnose COPD in primary care? Does this incorporate history, age, symptoms } \\
\text { and spirometry? }\end{array}$ \\
\hline Assessment & $\begin{array}{l}\text { Which measurements (spirometry, breathlessness scores, exercise tolerance, symptom/control scores, COPD-specific } \\
\text { or generic Quality of Life questionnaires) are feasible and provide useful information for routine monitoring and } \\
\text { assessing effectiveness of treatment in primary care worldwide }\end{array}$ \\
\hline Management & What is the best palliative treatment for severe dyspnoea? \\
\hline Assessment & $\begin{array}{l}\text { Are composite measures (such as the DOSE index or ADO-index) feasible in primary care within a range of healthcare } \\
\text { settings and valid compared with established indices (e.g. BODE) }\end{array}$ \\
\hline Co-morbidity & $\begin{array}{l}\text { What are the optimum treatment regimes (including the impact of polypharmacy) for people with COPD and } \\
\text { co-morbid conditions such as cardiovascular disease, diabetes or dementia? }\end{array}$ \\
\hline Assessment & $\begin{array}{l}\text { In the context of COPD, what are the key questions that accurately assess smoking history, provide a sensitive and } \\
\text { specific assessment of tobacco addiction and motivation for smoking cessation? }\end{array}$ \\
\hline Diagnosis & $\begin{array}{l}\text { What is the extent of under- (and over-diagnosis) of COPD in primary care communities in different countries, and to } \\
\text { what extent are patients who smoke (or exposed to burning biomass fuels) proactively screened for COPD? }\end{array}$ \\
\hline Diagnosis & $\begin{array}{l}\text { Which approach to early COPD diagnosis in primary care is underpinned by the strongest clinical and health } \\
\text { economic evidence base (questionnaires and/or spirometry, screening or case finding)? }\end{array}$ \\
\hline Pharmacological & $\begin{array}{l}\text { What is the role of low-dose theophylline, especially in low income countries where it may be one of the few } \\
\text { treatments available? }\end{array}$ \\
\hline Management & $\begin{array}{l}\text { How should people with GOLD mild or moderate COPD be managed in primary care with regard to lifestyle advice } \\
\text { (smoking cessation, dietary advice), therapeutic treatment (anti-inflammatory and/or bronchodilators), and physical } \\
\text { activity (pulmonary rehabilitation) in order to improve outcomes in different healthcare settings? }\end{array}$ \\
\hline CPD & What is an appropriate standard of spirometry training for primary care clinicians? \\
\hline Co-morbidity & $\begin{array}{l}\text { Which are the most prevalent co-morbidities in people with COPD in different countries and what examinations and } \\
\text { tests should be undertaken routinely in order to detect co-morbidities? }\end{array}$ \\
\hline Diagnosis & What are the essential parameters (e.g. $\mathrm{FEV}_{1} / \mathrm{FVC}$ and/or $\mathrm{FEV}_{1} / \mathrm{FEV}_{6}$, inspiratory measurements) of spirometry in primary care? \\
\hline Organisation & $\begin{array}{l}\text { How should the self-management education programme be adapted for different severities of disease and/or } \\
\text { different healthcare systems? }\end{array}$ \\
\hline Self-management & $\begin{array}{l}\text { What is the optimal format of self-management education (including the information content, individualisation of the } \\
\text { plan, written or electronic delivery, professional or lay educators) in order to ensure effective communication with } \\
\text { patients (often from deprived communities), facilitation of adherence to treatment, and a positive impact on health status? }\end{array}$ \\
\hline Pharmacological & $\begin{array}{l}\text { Should choice, dose, and duration of treatment (oral corticosteroids, antibiotics) be different for different severity of } \\
\text { COPD and severity of exacerbations? Is there a role for inhaled steroids in exacerbations of COPD? }\end{array}$ \\
\hline Assessment & $\begin{array}{l}\text { What impact does immediate access to investigations (e.g. chest x-ray, oxygen saturation, C reactive protein) have on } \\
\text { the primary care management of people with acute exacerbations of COPD and the decision to refer? }\end{array}$ \\
\hline
\end{tabular}

cause of nasal symptoms and management strategies), two in the COPD domain (diagnosis in primary care) and one in the respiratory infections domain (identifying when antibiotics were indicated). The 83 questions not prioritised are listed in Appendices 1-5, available online at www.thepcrj.org.

\section{Over-arching themes}

The questions were allocated to 12 categories (listed in Table
2). Comparison of the relative proportion of questions from each category prioritised at the $80 \%$ and $90 \%$ thresholds with the 145 questions of the RNS illustrates the prioritisation process; for example, $40(28 \%)$ of the 145 questions in the RNS related to diagnosis or assessment. These questions were actively prioritised, accounting for $29(46 \%)$ of the 62 questions which achieved consensus at the $80 \%$ level and 16 
Table 6. Consensus on the research priorities in tobacco dependence listed in rank order

\begin{tabular}{ll} 
Category & Research question \\
\hline Management & $\begin{array}{l}\text { How can brief advice be used more effectively to increase motivation to quit, and what elements are most efficient for a } \\
\text { busy primary care practitioner? }\end{array}$ \\
\hline Assessment & $\begin{array}{l}\text { What questions provide the most sensitive and specific assessment of tobacco dependence and motivation to quit, and of } \\
\text { the smoker's individual needs? }\end{array}$ \\
\hline Prevention & How can primary care clinicians in different countries be made more aware of strategies to prevent smoking in young \\
& people and in pregnancy? \\
\hline Organisation & $\begin{array}{l}\text { What models of providing smoking cessation services overcome known barriers (e.g. time, accessibility, expertise) } \\
\text { and are acceptable, feasible, effective, and cost-effective in primary care settings worldwide? }\end{array}$ \\
\hline Organisation & How can brief advice be implemented in different healthcare systems and different clinical (e.g. pregnancy, existing \\
& chronic obstructive pulmonary disease or heart disease, asthma, high risk groups) and psychosocial situations (e.g. those \\
not planning a quit attempt)?
\end{tabular}

Table 7. Consensus on the research priorities in respiratory infections listed in rank order

\begin{tabular}{ll} 
Category & Research question \\
\hline Diagnosis & $\begin{array}{l}\text { How can primary care clinicians reliably identify patients who would benefit from antibiotic therapy? What diagnostic } \\
\text { criteria are used in deciding on antibiotic treatment in high, middle and low income countries in primary healthcare settings? }\end{array}$ \\
\hline Assessment & How can primary care clinicians differentiate between serious and self-limiting LRTIs? \\
\hline Further tests & $\begin{array}{l}\text { Which near patient tests can contribute to cost-effective management of LRTI in primary care by reducing } \\
\text { inappropriate antibiotic use without compromising outcomes? }\end{array}$ \\
\hline Assessment & Which subgroups of patients with LTRIs need antibiotic treatment? \\
\hline Management & $\begin{array}{l}\text { Should management strategies for LRTI be different in subgroups with various co-morbidities, in smokers, in the } \\
\text { elderly, in children, and in pregnant women? }\end{array}$ \\
\hline LRTI = lower respiratory tract infections.
\end{tabular}

$(67 \%)$ of the 24 questions achieving $90 \%$ agreement. This process is illustrated for each of the categories in Figure 2.

\section{Discussion \\ Main findings}

The five disease areas all included priorities for the international primary care expert group in our study and a range of specific questions were highlighted within each domain. A number of overarching priorities could be identified. The need for 'simple tools' for establishing a diagnosis and assessing severity within low-technology consultations in primary care were prioritised over more complex investigations, broad management strategies were of more interest than evidence about efficacy of individual treatments, and practical approaches were sought for supporting self-management and lifestyle change.

\section{Strengths and limitations of this study}

Our expert panel of 23 primary care clinicians is unlikely to have represented the full range of perspectives from communitybased care globally. In many countries primary healthcare is poorly developed with no co-ordinating body that can represent their views, and other techniques will be required to explore their views. However, our participants were all actively involved in primary care and represented 21 countries with a broad range of economic backgrounds and healthcare systems. This is a similar number to expert panels in other reported e-Delphi studies. ${ }^{18,19}$ Importantly, all the participants contributed to all three rounds, enabling a consensus to be reached.

We did not formally request free text contributions (although suggestions could have been made in the covering e-mail) because the aim of the e-Delphi process was to prioritise the existing questions from the RNS which had already attracted contributions from the global membership of the IPCRG. ${ }^{9}$

Categorising the questions proved useful for identifying overarching themes but had the limitation that some questions 
could have fitted more than one category. For example, some of the questions coded as 'management' overlapped with 'organisation of care'. Although it was an overarching theme of the RNS, ${ }^{9}$ we did not include a category for guideline implementation because the relevant questions were already included as disease-specific priorities.

\section{Interpretation of findings in relation to previously published work}

In line with global priorities, ${ }^{1,3,4,7,8}$ a recently published research agenda for prevention and control of chronic respiratory diseases from the public health perspective highlighted the role of primary care in meeting the challenge of respiratory NCDs. ${ }^{5}$ Our findings complement this paper by defining the evidence needed to inform management of common respiratory conditions in primary care settings. There was universal agreement (from relatively well-resourced healthcare systems as well as low and middle income countries) that there was a need in all the disease domains to understand better the role of asking the right questions, using questionnaires and 'simple' investigations readily available in all surgeries to identify, diagnose, and assess patients with respiratory disease. This was not to downgrade the importance of diagnostic investigations (indeed, achieving standards for primary care spirometry was one of the prioritised questions) but recognises that access to such investigations may be limited in many healthcare systems and that there is a need to maximise the potential of what can be achieved with minimal equipment in a consultation. A recent example which resonates with the stepwise approach to diagnosing respiratory disease advocated by the Global Alliance against Chronic Respiratory Diseases ${ }^{4}$ is the identification of potential COPD with a short questionnaire and a Piko- $6^{\circledR}$ meter enabling targeted spirometry. ${ }^{21}$

The recognised challenge of diagnosing community-acquired pneumonia in primary care and, more pragmatically, deciding which patients with chest infections should be treated with antibiotics was highlighted as a research priority by our expert panel. A recent consensus initiative has developed definitions of respiratory infections which 'maintain relevance to everyday practice and are not over-reliant on investigations' which it is hoped will be more resonant with the needs of primary care research and clinical practice. ${ }^{22}$ Reinforcing the overarching theme of adopting a 'primary care approach', adapting evidence from hospital settings may be unhelpful. For example, the CRB65 score $^{23}$ designed to predict outcome in confirmed pneumonia in secondary care has been shown not to be helpful to the primary care clinician deciding on a management strategy without the benefit of a chest $x$-ray. ${ }^{24}$

Overall management strategies were of more interest than the efficacy of specific drugs or treatments, reflecting the recent interest in 'real-life' studies. ${ }^{11,12}$ Such studies not only inform the use of different therapeutic options in unselected populations ${ }^{9}$ but also provide evidence for how care may be organised to meet the needs of practice populations. ${ }^{25}$ Guidelines, typically reliant on evidence from traditional randomised clinical trials, are complemented by real-world studies to inform implementation. ${ }^{26,27}$

\section{Implications for future research, policy and practice}

Policy documents and research agendas universally agree that primary care is an important component of the fight against NCDs. ${ }^{1,3,4,5,7,78}$ Our prioritisation exercise contributes to the debate by highlighting the basic pragmatic questions which tax primary care clinicians globally. Crucially, evidence is needed about how - with only the 'simple' tools available in a consultation - a diagnosis may be suspected and a known respiratory condition assessed. Effective management strategies need to be informed by research recruiting populations typical of the broad spectrum of primary care.

It is our hope and expectation that this global prioritisation exercise will act as a stimulus to researchers, funders, and commissioners to focus research efforts on the areas of greatest need. Reflecting the diversity of healthcare systems in low, middle, and high income countries, many of the priority areas can be addressed by appropriately designed and funded projects in individual countries tailored to local recruitment, feasibility, sociocultural, and funding issues. Some priorities may be best addressed through multinational collaboration. Although the IPCRG is unable to commission or fund projects systematically, it can focus its expertise and support on small-scale pilot work which underpins programmes of work in line with the priorities, and broker international collaboration such as the UNLOCK project. ${ }^{28}$ The IPCRG research network will continue to monitor, assess, and highlight ongoing primary care research needs, thus providing a robust platform on which grass-root level researchers can build as they seek to justify their projects to funding authorities.

\section{Conclusions}

The hope was expressed with the launch of the RNS that it would influence funders and researchers to prioritise real-life primary care respiratory research. In an era when 'comprehensive strengthening' of primary care is seen as an important component of the global response to the increasing burden of NCDs, ${ }^{1,29}$ this hope must become a reality.

\section{Handling editor Maureen George}

Acknowledgements We are grateful to all the members of the expert panel who gave their time and responded to the three rounds within the tight timeframe that we gave them: Niels H Chavannes, The Netherlands; Javiera Corbalan, Chile; Jaime Correia de Sousa, Portugal; John Fardy, Australia; Antonio Infantino, Italy; Alan Kaplan, Canada; Elzbieta Kryj-Radziszewska, Poland; Arnulf Langhammer, Norway; Elena Latysheva, Russia; Tan Tze Lee, Singapore; Christos Lionis, Greece; Karen Lisspers, Sweden; Charles Llor, Spain; Catalina Panaitescu, Romania; David Price, UK; Jim Reid, New Zealand; Sundeep Salvi, India; Antonius Schneider, Germany; Laura Stacul, Argentina; M arianne Stubbe Ostergaard, Denmark; Ron Tomlins, Australia; Nguyen Nhu Vinh, Vietnam; Hakan Yaman, Turkey. We also thank Professor Aziz Sheikh, Dr Allison Worth and Dr Elizabeth Grant for their helpful comments on an earlier draft. Katie Searles undertook the administration.

Conflicts of interest HP has received fees for lecturing or attending advisory groups from GlaxoSmithKline (GSK), AstraZeneca, Boeringher Ingelheim and has been sponsored to attend conferences by AstraZeneca, Boeringher Ingelheim/Pfizer, 
Napp pharmaceuticals. DR has received sponsorship from, lectured on behalf of or provided consultancy to AstraZeneca, ALK Abello, Novartis, Uriach, Mundipharma, Orion Pharma, MSD, Pfizer, Boehringer Ingelheim, and Almirall. He is Allergy lead for both the PCRS (UK) and PCRG. He is employed as clinical lead for COPD by East Midlands Strategic Health Authority and as Respiratory Commissioning lead by East and West CCGs. BS has received payment for lectures by AstraZeneca, Boehringer Ingelheim, Pfizer and MSD, for development of educational presentations by AstraZeneca and MSD, and payment for national consultancy meetings with AstraZeneca, MSD, Boehringer Ingelheim, Nycomed, and GSK. Neither MT nor any member of his close family has any shares in pharmaceutical companies. He has received speaker's honoraria for speaking at sponsored meetings from the following companies marketing respiratory and allergy products: AstraZeneca, Boehringer Ingleheim, GSK, MSD, Napp, Schering-Plough, and Teva. He has received honoraria for attending advisory panels with AstraZeneca, Boehringer Ingleheim, GSK, MSD, Merck Respiratory, Schering-Plough, Teva, Abbott, and Novartis. He has received sponsorship to attend international scientific meetings and has received funding for research projects from GSK, MSD, and AstraZeneca. He held a research fellowship and is Chief Medical Advisor to Asthma UK. He is a member of the UK Department of Health Asthma Strategy Group and Home Oxygen Group, the MHRA Respiratory and Allergy Expert Advisory Group, the BTS SIGN Asthma Guideline Group, and the EAAACI Rhinosinusitis (EPOS) Guideline Group. SW is Executive Officer of the IPCRG, a charity that has as its mission the dissemination of research for the public good. We hope that publication of this study may increase global investment in reallife pragmatic respiratory research and IPCRG may be one of the beneficiaries of that investment. She declares this interest, although does not judge it to be a conflict. AO, MRR, IT, and OY have declared no conflicts of interest.

Contributorship HP with OY initiated the idea for the study and led the development of the protocol, supervised the study administration, data analysis, interpretation of results, and writing of the paper. All the authors contributed to the protocol, helped with piloting the process and supported the analysis, interpretation and writing of the paper. All authors reviewed the final manuscript. HP is the study guarantor.

Funding The International Primary Care Respiratory Group supported the administration of the e-Delphi. HP is supported by a Primary Care Research Career Award from the Chief Scientist's Office, Scottish Government. MT's academic position is supported by Asthma UK.

\section{References}

1. United Nations General Assembly: Sixty-sixth session. Political declaration of the High-level Meeting of the General Assembly on the Prevention and Control of Noncommunicable Diseases. New York: United Nations, 2011.

2. International Primary Care Respiratory Group. IPCRG campaigns. http://www.theipcrg.org/campaigns/index.php (accessed October 2011).

3. Non-Communicable Disease Alliance. Proposed outcomes document for the United Nations high level summit on non-communicable diseases. Geneva: NCD Alliance, 2010. http://www.ncdalliance.org/od (accessed October 2011).

4. World Health Organization. Global Alliance against Chronic Respiratory Diseases. Global surveillance, prevention and control of chronic respiratory diseases: a comprehensive approach. Geneva: World Health Organization, 2007.

5. Bousquet J, Kiley J, Bateman ED, et al. Prioritised research agenda for prevention and control of chronic respiratory diseases. Eur Respir J 2010;36:995-1001. http://dx.doi.org/10.1183/09031936.00012610

6. McCarthy M, Maher D, Ly A, Ndip A. Developing the agenda for European Union collaboration on non-communicable diseases research in sub-Saharan Africa. Health Res Policy Syst 2010;8:13. http://dx.doi.org/10.1186/1478-4505-8-13

7. World Health Organization. 2008-2013 Action Plan for the global strategy for the prevention and control of non-communicable diseases. Geneva: World Health Organization, 2008

8. World Health Organization. Global alliance against chronic respiratory diseases. Action Plan 2008-2013. Geneva: World Health Organization, 2008.
9. Pinnock H, Thomas M, Tsiligianni I, et al. The International Primary Care Respiratory Group (IPCRG) Research Needs Statement 2010. Prim Care Respir J 2010;19(Supp 1):S1-S21. http://dx.doi.org/10.4104/pcrj.2010.00021

10. Price $D$, M usgrave SD, Shepstone $L$, et al. Leukotriene antagonists as first-line or addon asthma-controller therapy. N Engl J Med 2011;364:1695-707. http://dx.doi.org/10.1056/NEJM oa1010846

11. Dahlén S-E, Dahlén $B$, Drazen JM. Asthma treatment guidelines meet the real world. N Engl J Med 2011;364:1769-70. http://dx.doi.org/10.1056/NEJMe1100937

12. Ducharme FM . Leukotriene receptor antagonists as first line or add-on treatment for asthma. BMJ 2011;343:d5314. http://dx.doi.org/10.1136/bmj.d5314

13. Dalkey $N$, Helmer 0 . An experimental application of the Delphi method to the use of experts. Manage Sci 1963;9:458-67. http://dx.doi.org/10.1287/mnsc.9.3.458

14. Hasson F, Keeney S, McKenna H. Research guidelines for the Delphi survey technique. J Advanced Nursing 2000;32:1008-15.

15. Okoli C, Pawlowski SD. The Delphi method as a research tool: an example, design considerations and applications. Inform Manage 2004;42:15-29. http://dx.doi.org/10.1016/j.im.2003.11.002

16. Powell C. The Delphi technique: myths and realities. I Advanced Nursing 2003;41:376-82. http://dx.doi.org/10.1046/j.1365-2648.2003.02537.x

17. Murphy MK, Sanderson CFB, Black NA, et al. Consensus development methods and their use in clinical guideline development. Health Technol Assess 1998;2(3):1-88.

18. Worth A, Nurmatov U, Sheikh A. Key components of anaphylaxis management plans: consensus findings from a national electronic Delphi study. J R Soc M ed Sh Rep 2010;1:42.

19. Avery A J, Savelyich BSP, Sheikh A, et al. Identifying and establishing consensus on the most important safety features of GP computer systems: e-Delphi study. Informatics Prim Care 2005;13:3-11.

20. Sheikh A, Major $P$, Holgate ST. Developing consensus on national respiratory research priorities: key findings from the UK Respiratory Research Collaborative's e-Delph exercise. Respir Med 2008;102:1089-92. http://dx.doi.org/10.1016/ j.rmed.2008.03.006

21. Sichletidis L, Spyratos D, Papaioannou M, et al. A combination of the IPAG questionnaire and PiKo- $6{ }^{\circledR}$ flow meter is a valuable screening tool for COPD in the primary care setting. Prim Care Respir J 2011;20:184-9. http://dx.doi.org/10.4104/pcrj.2011.00038

22. Greene G, Hood K, Little P, et al. Towards clinical definitions of lower respiratory tract infection (LRTI) for research and primary care practice in Europe: an international consensus study. Prim Care Respir J 2011;20:299-306. http://dx.doi.org/10.4104/pcrj.2011.00034

23. Lim WS, Baudouin SV, George RC, et al. BTS guidelines for the management of community acquired pneumonia in adults: update 2009. Thorax 2009;64(Suppl 3):iii1-55. http://dx.doi.org/10.1136/thx.2009.121434

24. Francis NA, Cals JW, Butler CC, et al, on behalf of the GRACE Project Group. Severity assessment for lower respiratory tract infections: potential use and validity of the CRB-65 in primary care. Prim Care Respir J 2012;21(1):65-70. http://dx.doi.org/10.4104/pcrj.2011.00083

25. Pinnock H, Adlem L, Gaskin S, Harris J, Snellgrove C, Sheikh A. Accessibility, clinical effectiveness and practice costs of providing a telephone option for routine asthma reviews: controlled implementation study. Br J Gen Pract 2007;57:714-22.

26. Holgate $S$, Bisgaard $H$, Bjermer $L$, et al. The Brussels Declaration: the need for change in asthma management. Eur Respir J 2008;32:1433-42. http://dx.doi.org/10.1183/09031936.00053108

27. Olesen F. Putting research into clinical practice. BMJ 2011;343:d3922. http://dx.doi.org/10.1136/bmj.d3922

28. Chavannes N, Stallberg B, Lisspers K, et al. UNLOCK: Uncovering and Noting Longterm Outcomes in COPD to enhance Knowledge. Prim Care Respir J 2010;19:408. http://dx.doi.org/10.4104/pcrj.2010.00084

29. World Health Organization. Global status report on non-communicable diseases 2010. Geneva: World Health Organization, 2010.

Available online at http://w ww whepcrj.org 
Appendix 1. Research questions in asthma which did not reach $80 \%$ consensus threshold

\begin{tabular}{|c|c|c|}
\hline Category & Research question & Agreement \\
\hline Organisation & $\begin{array}{l}\text { Are any models of healthcare better than others in terms of clinical and cost effectiveness for } \\
\text { management of asthma? }\end{array}$ & $78 \%$ \\
\hline Co-morbidity & $\begin{array}{l}\text { Does the detection and treatment of co-morbidities (anxiety and depression, obesity) improve } \\
\text { outcomes for people with asthma? }\end{array}$ & $78 \%$ \\
\hline Diagnosis & $\begin{array}{l}\text { To what extent are small children with recurrent wheeze misdiagnosed in primary care and with } \\
\text { what consequences for morbidity? }\end{array}$ & $78 \%$ \\
\hline Prevention & $\begin{array}{l}\text { What are the important environmental risk factors (including indoor biomass fuel smoke, cigarette } \\
\text { smoking and environmental pollution, aeroallergens, dietary and lifestyle factors) in different countries } \\
\text { and what preventative measures can effectively reduce the prevalence and severity of asthma? }\end{array}$ & $78 \%$ \\
\hline Organisation & $\begin{array}{l}\text { What is the role of mobile technology, web resources and remote consultations in the management } \\
\text { of patients in primary care? }\end{array}$ & $78 \%$ \\
\hline Organisation & $\begin{array}{l}\text { How can services be configured to ensure that frontline clinical staff assess and manage acute asthma } \\
\text { attacks according to evidence-based practice? }\end{array}$ & $74 \%$ \\
\hline Co-morbidity & How do co-morbidities impact on asthma control and management? & $74 \%$ \\
\hline Diagnosis & Is it possible to predict persisting asthma in children with wheeze in primary care? & $74 \%$ \\
\hline Self-management & $\begin{array}{l}\text { What are the appropriate elements of self-management education and how can it best be conveyed to } \\
\text { the patient/family in routine practice? }\end{array}$ & $74 \%$ \\
\hline Diagnosis & $\begin{array}{l}\text { What are the reliability, validity and feasibility of different diagnostic tools such as spirometry, peak flow } \\
\text { measurement, challenge tests, exhaled nitric oxide, and allergy testing in the diagnosis of asthma in primary care? }\end{array}$ & $74 \%$ \\
\hline Pharmacological & $\begin{array}{l}\text { How do ICS and LTRAs compare with regard to effectiveness and side-effects in patients with mild and } \\
\text { moderate asthma in real-life primary care practice? }\end{array}$ & $70 \%$ \\
\hline Self-management & $\begin{array}{l}\text { How, and to what degree, are asthma action plans implemented in various communities, especially in low } \\
\text { and middle income countries, and how do they impact on asthma morbidity and mortality? }\end{array}$ & $70 \%$ \\
\hline Management & What is the most cost-effective approach to inhaler devices? & $70 \%$ \\
\hline Self-management & Why do patients accept suboptimal asthma control and how can we address the reasons? & $70 \%$ \\
\hline Organisation & What are the indications for referral to an emergency unit? & $65 \%$ \\
\hline Management & What is the impact of different treatments for wheezing in young children in primary care? & $65 \%$ \\
\hline Management & $\begin{array}{l}\text { What is the impact of non-pharmacological strategies (e.g. breathing modification, allergen avoidance } \\
\text { techniques) in the management of asthma symptoms? }\end{array}$ & $65 \%$ \\
\hline Diversity & $\begin{array}{l}\text { What is the influence of cultural and ethnic beliefs towards asthma and how do these beliefs affect } \\
\text { outcome in management of asthma in these communities? }\end{array}$ & $65 \%$ \\
\hline Diversity & What strategies are needed to counteract the taboos associated with inhaler usage in some countries? & $65 \%$ \\
\hline CPD & $\begin{array}{l}\text { Are primary care physicians aware of the allergens and respiratory irritants in their area? Are they aware } \\
\text { of the preventive measures against such asthma triggers? }\end{array}$ & $26 \%$ \\
\hline Assessment & $\begin{array}{l}\text { Can specific asthma phenotypes be identified in primary care and what are the implications for treatment } \\
\text { and management in primary care? }\end{array}$ & $26 \%$ \\
\hline Further tests & $\begin{array}{l}\text { What are the cut-off values for abnormal spirometry (lower limit of normal), reversibility tests and diurnal } \\
\text { variation of peak flow measurement across a broad range of age groups and ethnicity? }\end{array}$ & $26 \%$ \\
\hline Diagnosis & $\begin{array}{l}\text { What is the reliability of a medication trial for diagnosing asthma in different ages, how should such tests } \\
\text { be performed, using which treatments and for how long? }\end{array}$ & $22 \%$ \\
\hline Diversity & $\begin{array}{l}\text { How might asthma action plans be tailored for different cultural and ethnic groups taking into account } \\
\text { their own cultural beliefs and practices? }\end{array}$ & $17 \%$ \\
\hline Diagnosis & What strategies will improve detection and prevention of occupational asthma in primary care? & $17 \%$ \\
\hline Self-management & How should action plans accommodate the different asthma treatment schedules? & $9 \%$ \\
\hline Assessment & $\begin{array}{l}\text { What is the role of nitric oxide, mannitol challenge testing (or other innovative techniques) in the } \\
\text { monitoring of asthma in primary care? }\end{array}$ & $4 \%$ \\
\hline
\end{tabular}


Appendix 2. Research questions in allergic rhinitis which did not reach $80 \%$ consensus threshold

\begin{tabular}{|c|c|c|}
\hline Category & Research question & Agreement \\
\hline Co-morbidity & $\begin{array}{l}\text { How should patients with other respiratory conditions (eg asthma, COPD, sleep apnoea), or other } \\
\text { co-morbidities (e.g. hypertension, diabetes mellitus, heart disease, liver disease) or physiological states } \\
\text { (e.g. pregnancy, extremes of age) be managed? }\end{array}$ & $78 \%$ \\
\hline Diagnosis & What are the essential components of physical examination in primary care? & $78 \%$ \\
\hline Diversity & $\begin{array}{l}\text { What is the cost-effectiveness of different treatment regimens in healthcare systems with diverse } \\
\text { socio-economic and financial status? }\end{array}$ & $78 \%$ \\
\hline CPD & What is the current state of knowledge about the diagnosis and management of rhinitis in primary care? & $78 \%$ \\
\hline Self-management & Are patients information needs being met, with accurate, easily accessible, and culturally sensitive resources? & $74 \%$ \\
\hline Epidemiology & What is the hidden burden of undiagnosed allergic rhinitis in different countries? & $70 \%$ \\
\hline Self-management & What strategies can be used to reduce the risk of side-effects from self-treatment? & $70 \%$ \\
\hline Pharmacological & $\begin{array}{l}\text { What evidence is there for the safety and efficacy of systemic steroids in the treatment of rhinitis? Are there } \\
\text { differences between existing systemic therapies (e.g. oral, intramuscular?) }\end{array}$ & $61 \%$ \\
\hline Pharmacological & $\begin{array}{l}\text { For which patients is immunotherapy (sublingual or injection) appropriate, safe and cost effective? } \\
\text { Should such treatment always involve a referral for a specialist care? }\end{array}$ & $27 \%$ \\
\hline Diversity & $\begin{array}{l}\text { What is the availability of over-the-counter remedies in different countries, and the diagnostic and } \\
\text { management skills of those who sell or advise on their administration? }\end{array}$ & $26 \%$ \\
\hline Diagnosis & $\begin{array}{l}\text { What is the value of, and how feasible are skin-prick tests and other tests in the diagnosis and } \\
\text { management of allergic rhinitis in primary care in diverse healthcare settings? Does performance of these } \\
\text { tests affect clinical outcomes? }\end{array}$ & $26 \%$ \\
\hline Management & $\begin{array}{l}\text { What is the acceptability to patients and impact on the morbidity of rhinitis / asthma of physical measures } \\
\text { (e.g.nasal douches, nasal lubricants, closing windows at night) }\end{array}$ & $13 \%$ \\
\hline Self-management & What non pharmacological remedies do patients use to treat their rhinitis? & $13 \%$ \\
\hline Self-management & $\begin{array}{l}\text { To what extend do patients with allergic rhinitis use alternative medicines? (e.g. homeopathy, herbal } \\
\text { treatment etc)? }\end{array}$ & $9 \%$ \\
\hline Organisation & What is the optimal balance between generalist care and specialist allergy care in different healthcare systems? & $9 \%$ \\
\hline Assessment & $\begin{array}{l}\text { What role does allergen identification and avoidance have in the management of rhinitis? Does this } \\
\text { vary according to the geographic, climatic and demographic context? }\end{array}$ & $9 \%$ \\
\hline Further tests & $\begin{array}{l}\text { Does nitric oxide measurement have a role in the diagnosis and management of patients with allergic rhinitis } \\
\text { in primary care? }\end{array}$ & $4 \%$ \\
\hline
\end{tabular}




\section{Appendix 3. Research questions in COPD which did not reach $80 \%$ consensus threshold}

\begin{tabular}{|c|c|c|}
\hline Category & Research question & Agreement \\
\hline \multirow[t]{2}{*}{ Co-morbidity } & To what extent do primary care clinicians screen people with COPD for depression using appropriate & \\
\hline & validated screening tools? & $78 \%$ \\
\hline Organisation & How can clinical services be organised within different healthcare systems to support self-care? & $74 \%$ \\
\hline Further tests & $\begin{array}{l}\text { Should a chest x-ray always be done as part of an initial assessment, regardless of the severity of COPD } \\
\text { at diagnosis? }\end{array}$ & $70 \%$ \\
\hline Management & $\begin{array}{l}\text { What is the impact (e.g on smoking cessation rates, identification of COPD) of routinely undertaking } \\
\text { spirometry in smoking cessation consultations? }\end{array}$ & $70 \%$ \\
\hline Diagnosis & $\begin{array}{l}\text { Is it best to use a fixed ratio or LLN of FEV1/FVC? What are the characteristics of patients in the community } \\
\text { who are diagnosed with COPD according to the fixed ratio formula and not according to the LLN? }\end{array}$ & $68 \%$ \\
\hline Prevention & $\begin{array}{l}\text { What impact does screening for and taking action (pharmacological and/or physical activity) to prevent } \\
\text { osteoporosis/fractures have on morbidity? }\end{array}$ & $61 \%$ \\
\hline Organisation & What are the core requirements for a community based pulmonary rehabilitation service? & $57 \%$ \\
\hline Organisation & How can carers and family members be supported? & $30 \%$ \\
\hline Prevention & $\begin{array}{l}\text { What is the impact of locally tailored community-level measures to decrease exposure to indoor smoke and } \\
\text { reduce harm? }\end{array}$ & $30 \%$ \\
\hline Organisation & $\begin{array}{l}\text { What is the role of tele-monitoring? Does it reduce admissions and/or improve the quality of life for people } \\
\text { with COPD? For which patients, and under what circumstances does it work best? }\end{array}$ & $26 \%$ \\
\hline Organisation & What are the social care needs? Is it possible to integrate social and clinical care? & $22 \%$ \\
\hline Organisation & $\begin{array}{l}\text { What organisational approaches (e.g. primary care registers, public health campaigns) are most effective } \\
\text { in facilitating good uptake of seasonal flu vaccination? }\end{array}$ & $22 \%$ \\
\hline Organisation & $\begin{array}{l}\text { How can health and social care services be developed to meet the needs of people with severe COPD } \\
\text { within different cultural and healthcare systems? }\end{array}$ & $17 \%$ \\
\hline CPD & $\begin{array}{l}\text { How can primary care clinicians overcome the 'paralysis' that results from the uncertain prognosis in order } \\
\text { to deliver proactive supportive care? }\end{array}$ & $13 \%$ \\
\hline Organisation & What is the role of the voluntary sector? How can the public profile of COPD be raised? & $13 \%$ \\
\hline CPD & $\begin{array}{l}\text { What professional skills are required by clinical teams providing integrated care for people with COPD within } \\
\text { diverse healthcare systems? }\end{array}$ & $13 \%$ \\
\hline
\end{tabular}




\section{Appendix 4. Research questions in tobacco dependence which did not reach $80 \%$ consensus threshold}

\begin{tabular}{ll} 
Category & Research question \\
\hline Management & $\begin{array}{l}\text { What psychosocial factors (family, alcoholism, depression etc) affect ability to quit and how may these } \\
\text { be overcome? }\end{array}$ \\
\hline CPD & $\begin{array}{l}\text { How can awareness of the public health importance of tobacco dependence - both among smokers and } \\
\text { the primary care professionals - be raised? }\end{array}$ \\
\hline Management & What is the impact of regular and non-judgmental advice to quit on long-term quit rates? \\
\hline Compliance & What strategies improve adherence with pharmacotherapeutic agents for smoking cessation? \\
\hline Prevention & $\begin{array}{l}\text { What is the impact of primary care interventions on exposure of children to environmental tobacco smoke } \\
\text { and prevention of smoking in young people? }\end{array}$ \\
\hline Organisation & $\begin{array}{l}\text { What factors increase the uptake and effectiveness of telephone (and internet) quitline services and how may } \\
\text { they be optimised? }\end{array}$ \\
\hline Pharmacological & $\begin{array}{l}\text { What is the clinical and cost effectiveness of nicotine vaccines in assisting smoking cessation and what is } \\
\text { their role in primary care populations? }\end{array}$ \\
\hline
\end{tabular}


Appendix 5. Research questions in respiratory infections which did not reach $80 \%$ consensus threshold

\begin{tabular}{|c|c|c|}
\hline Category & Research question & Agreement \\
\hline Management & $\begin{array}{l}\text { Do primary care clinicians follow guidelines such as British Thoracic Society CAP guideline or SIGN LTRI } \\
\text { guideline in their daily practice? }\end{array}$ & $78 \%$ \\
\hline Pharmacological & $\begin{array}{l}\text { If antibiotics are used, what are appropriate first-line choices and to what extent do local factors determine } \\
\text { antibiotic choice? }\end{array}$ & $78 \%$ \\
\hline Further tests & $\begin{array}{l}\text { What investigations for respiratory infections are available in primary care in different countries (eg x-ray, } \\
\text { leucocyte count, } C \text { reactive protein, erythrocyte sedimentation rate) and how does the use of these } \\
\text { ancillary tests affect antibiotic use and clinical outcomes in these countries? }\end{array}$ & $78 \%$ \\
\hline Self-management & $\begin{array}{l}\text { Can the use of patient education and information strategies improve patient satisfaction and reduce } \\
\text { inappropriate antibiotic use? }\end{array}$ & $74 \%$ \\
\hline Organisation & What is the role of primary care in pandemic respiratory infections? & $74 \%$ \\
\hline Management & Can deferred prescription strategies reduce antibiotic use without compromising outcomes? & $70 \%$ \\
\hline Prevention & How can uptake rates for vaccination be improved? & $70 \%$ \\
\hline Prevention & $\begin{array}{l}\text { Is there a role for primary care in smoking cessation, nutritional and other preventative programmes to } \\
\text { reduce LRTIs in the community? }\end{array}$ & $61 \%$ \\
\hline Prevention & What are the most effective strategies for prevention and reduction of transmission of LRTIs? & $39 \%$ \\
\hline Pharmacological & How should antivirals be used in primary healthcare? & $30 \%$ \\
\hline Compliance & $\begin{array}{l}\text { What is the compliance (adherence and persistence) with different antibiotic treatment regimens? In healthcare } \\
\text { systems which allow patients to obtain antibiotics over-the-counter, what is the effect on compliance, on } \\
\text { outcomes and on resistance rates? To what extent do people use antibiotic 'left-overs' in the community? }\end{array}$ & $26 \%$ \\
\hline Management & $\begin{array}{l}\text { What is the role of over-the-counter and non-pharmacological therapies in the management of the symptoms } \\
\text { of LRTI? }\end{array}$ & $22 \%$ \\
\hline Management & $\begin{array}{l}\text { Do primary care clinicians consider the cost of medications to the patient, and does cost and availability } \\
\text { of medication affect outcomes? }\end{array}$ & $17 \%$ \\
\hline Diversity & Should treatment approaches to LRTI be the same in high, middle and low income countries? & $17 \%$ \\
\hline Organisation & What determines how long patients wait (delay?) before consulting with their GP? & $13 \%$ \\
\hline Further tests & Is it warranted and feasible to use virology testing in primary care? & $9 \%$ \\
\hline
\end{tabular}

